\section{Capturing a community's vision as a pattern language: Case study of the Mooiplaas community in Great Kei Municipality, South Africa}

\section{Ronald Eglin}

\author{
DOI: http://dx.doi.org/10.18820/2415-0495/trp76i1.3 \\ Peer reviewed and revised December 2019 \\ *The authors declared no conflict of interest for this title or article
}

\begin{abstract}
Existing tools for capturing a community's vision during a spatial planning and land-use management exercise often do not adequately articulate a community's vision in an inspiring way and in a way that planners and the community are able to communicate what the vision actually means. The 'pattern language' approach, pioneered by Christopher Alexander and others, is introduced as a possible 'new' approach in South Africa that can be used to articulate a community's vision as part of a municipal spatial development framework planning process. It is shown, based on qualitative research conducted at Mooiplaas, in the Great Kei Municipality in the Eastern Cape province of South Africa, that a preliminary pattern language can be developed by working with a specific community to identify those features of their community they would like to retain and improve as well as what new features they would like to introduce into their community based on their vision. Areas for further research related to the 'pattern language' concept are identified.
\end{abstract}

Keywords: Christopher Alexander, communal land, land-use management, pattern language, South Africa, spatial planning

\section{'N GEMEENSKAP SE VISIE VASGELÊ AS PATROONTAAL: GEVALLESTUDIE VAN DIE MOOIPLAAS-GEMEENSKAP IN DIE GROOT KEI-MUNISIPALITEIT, SUID-AFRIKA}

Bestaande instrumente om 'n gemeenskap se visie vas te lê tydens ruimtelike beplanning en -bestuur van grondgebruik artikuleer dikwels nie die visie van 'n gemeenskap op ' $n$ inspirerende manier en op 'n manier waarop beplanners en die gemeenskap kan kommunikeer oor wat die visie eintlik beteken nie. Die 'patroontaal'-benadering wat deur Christopher Alexander en andere gepionier is, word in Suid-Afrika as 'n moontlike 'nuwe' benadering bekendgestel wat gebruik kan word om 'n gemeenskap se visie te verwoord as deel van 'n munisipale ruimtelike ontwikkelingsraamwerk. Dit word getoon, gebaseer op kwalitatiewe navorsing wat by Mooiplaas, in die Groot Kei-munisipaliteit in die Oos-Kaapse provinsie van Suid-Afrika gedoen is, dat 'n voorlopige patroontaal ontwikkel kan word deur met 'n spesifieke gemeenskap te werk om die kenmerke van hul gemeenskap te identifiseer wat hulle wil behou en verbeter, asook watter nuwe funksies hulle op grond van hul visie in hul gemeenskap wil inbring. Areas vir verdere navorsing rakende die 'patroontaal'-begrip word geïdentifiseer.

Sleutelwoorde: Christopher Alexander, bestuur van grondgebruik, gemeenskaplike grond, patroontaal, Suid-Afrika, ruimtelike beplanning

\section{BOHLAHISI BA PONELOPELE EA SECHABA ELE MOKHABO- PUO: BOITHUTO BA MOTSE OA MOOIPLAAS, 'MASEPALA OA GREAT KEI, AFRIKA BOROA}

Lisebelisoa tse teng tsa bohlahisi ha li fane ka setshwantsho se phethahetseng sa ponelopele ea sechaba nakong ea thero le tshebediso ea lefatshe, mme li sitisa ba thero ea litoropo le sechaba ho buisana ka seo pono e se bolelang. Mokhoa puisano ka mokhabo-puo, o tlileng ka Christopher Alexander le ba bang, o hlahisoa ele mokhwa o mocha, o ka sebelisoang naheng ea Afrika Borwa ho hlakisa ponelopele ea sechaba nakong ea thero ea moralo oa ntlafatso ea libaka. Boithuto ba boleng bo entsoeng Moiplaas, 'Masepaleng oa Great Kei, profinseng ea Kapa Bochabela, Afrika Boroa, bo bontsha hore mokhabo-puo oa pele o ka boptjoa ka ho sebetsa le karoloana ea sechaba ho supa linthla tse ikhethileng tsa sechaba ka kakaretso, tse lokelang ho ntlafatsoa, mmoho le tse ncha tseo ba li labalabelang ho latela ponelopele ea bona. Linthla tse ling tsa mokhabo-puo tse hlokang boithuto bo phethahetseng lia hlahisoa.

\section{INTRODUCTION}

Visions are an important feature of many planning processes and are used in the strategic planning process of organisations (Community Toolbox, n.d.; On Strategy, n.d.). Visions are also used in the Integrated Development Planning (IDP) process to provide a long-term vision of the municipality as per the Municipal Systems Act (MSA) (RSA, 2000: s26) and the development of Spatial Development Framework (SDF) plans of municipalities to provide a spatial vision for the area in future as per the Spatial Planning and Land Use Management Act (SPLUMA), No. 16 of 2013 (RSA, 2013: s21.c). Visions provide a clear image of the future that inspires and motivates purposeful action (Shipley, 2002: 14).

This article argues that existing tools such as vision statements, SDF plans and development principles used to capture a community's vision are insufficient for helping a community fully express their 
vision. It is suggested that additional visioning tools need to be explored in order to ascertain whether they may help improve the way in which a community's vision is developed and articulated.

The pattern language approach (Alexander, Ishikawa, Silverstein, Jackobson, Fiksdahl-King \& Angel, 1977; Alexander, 1979) is introduced as a possible candidate for a new approach and methodology that can be used to capture a community's vision. The pattern language is explained, and an example of a pattern language is provided. The process for how such a pattern language can be developed and written is outlined. Some initial thoughts are then provided as to how a pattern language can be used within the context of spatial planning and land-use management in South Africa. The article concludes by making recommendations for more research and work that needs to be done in order to pick up on some of the ideas introduced in the article.

\section{LITERATURE REVIEW}

\subsection{Visions}

A vision provides a description of a future to which one would like to aspire. A vision "is the notion of creating images of the future to serve as goals or guides for planning decisions" (Shipley, 2002: 7). $A$ vision is a long-term goal that one never reaches, but that one is always striving towards. Visions are usually associated with longer term aspirations, whereas goals and objectives describe medium- to shorter term aspirations. Goals and objectives are more specific, describing a tangible future state that is achievable, whereas visions describe a less precise and looser goal (Bhattacharyya, 2016: online).

In a municipal development and spatial planning process, the vision describes the broad direction in which the municipality wants to head. Strategies are then put in place to work towards this vision. Various goals and objectives are outlined as signposts to indicate whether these strategies are being implemented. Government implements programmes and projects in support of these strategies. The private sector and citizens generally also undertake actions and projects in line with these strategies. In theory, government, private sector and citizen actions all pursue the broader long-term vision.

The process of developing a vision - visioning - provides an opportunity for a community and associated professionals working with that community to come together and broadly agree on what future they are working towards and provides an opportunity to consider the areas of disagreement that need attention (Shipley, 2002). Various tools are used to capture or articulate a vision within the context of spatial planning. ${ }^{1}$ For example, a vision statement is a short statement of what one would like a space (region or community) to be in future. The spatial vision statement for the Great Kei Municipality (GKM), as expressed in its Integrated Development Plan (GKM, 2017: 85) is "[a]chieving a peaceful and sustainable environment where all communities enjoy an improved quality of life[,] affordable services, democratic governance and employment through thriving agriculture, commerce, SMMEs ${ }^{2}$ and tourism activities". In its preferred future scenario, the GKM goes on to express the following spatial vision: "[a] regenerated municipal area, catering for the existing and future needs of its residents, with enough water and other basic infrastructure to invite investors into the towns with confidence" (GKM, 2017: 87).

A spatial development framework (SDF) provides a spatial description of what one would like a particular geographic area to be in the future. Section 12(1) of SPLUMA (RSA, 2013) states that all SDFs must "(a) interpret and represent the spatial development vision of the responsible sphere of government

\footnotetext{
1 Many of these tools are also used in other contexts such as visions for country, organisational, or individual development.

2 SMME $=$ Small Medium and Micro Enterprise.
}

...; [and] (b) are informed by a long-term spatial development vision statement and plan" (emphasis added). Figure 1 provides an example of a vision - expressed as an SDF plan for the Great Kei Municipality. In line with the MSA No. 32 of 2000 (RSA, 2000: s16.1) public participation is required in the development of the IDP, of which the SDF is a part.

This public participation requirement is emphasised again in SPLUMA (RSA, 2013: 12.1(0)).

Visions are also expressed and described by means of development and spatial principles and guidelines. For example, the spatial principles found in section 2 of the SPLUMA can be used to inform a vision for the type of spatial landscape South Africa would like to see in future. This includes, for example, the principles of spatial justice, stating that "past spatial and other development imbalances must be redressed through improved access to and use of the land" (s7(a)(i)), and spatial sustainability, stating that special consideration needs to be "given to the protection of prime and unique agricultural land" (s7(b)(ii)).

Municipalities also make use of development and spatial principles. For example, two of the GKMs' spatial development objectives (GKM, 2017: 85) are "[t]o fulfil basic needs obligations and address spatial integration within available means", and "[r] educed unemployment through local economic skills development, access to land for emerging farmers and community tourism growth".

It is suggested in this article that none of these tools are able to adequately capture and articulate the full scope of what a particular community's vision is. The short vision statement only gives a small taste of what the vision is. It is difficult to perceive such a vision in one's "inner eye or the mind", as Alexander, Neis, Anninou and King (1987: 50) suggest a vision needs to be able to do. These vision statements are meant to inspire. But can one claim that one has been 


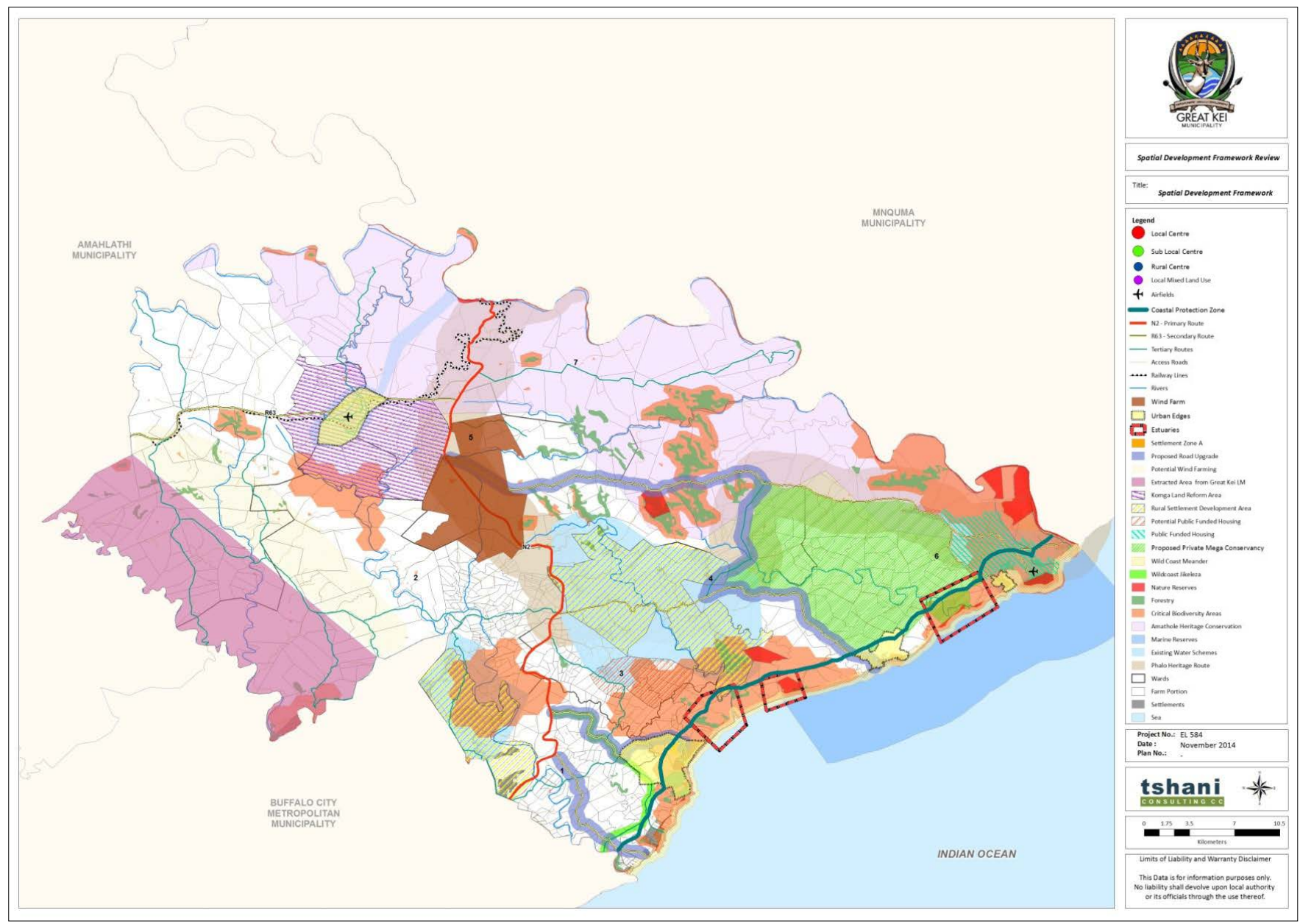

Figure 1:Example of municipal SDF for Great Kei Municipality

Source: GKM, 2016: $90^{3}$

truly inspired by a vision statement of an area or an organisation?

The SDF can be too static, fixing what an area should be like at some future date and not providing enough flexibility in how this 'vision' can be modified as conditions change over time. The municipality needs to follow a fairly lengthy and detailed process if it is to revise the SDF (Rural Development and Land Reform, 2011). In addition, these SDFs do not provide a textured finegrained insight of what people would, in fact, like an area to be in the future.

Development and spatial principles can be too abstract, making it difficult for people using these principles and guidelines to know exactly what to do in a particular context to express each principle. The SPLUMA principles are very broad; some

3 This is an unpublished document of this report received from the Town Planner at the GKM. A copy is available from the author on request. argue (South African Cities Network, 2015: 27-33) that they do not provide sufficient guidance in particular contexts on what actions need to be undertaken. On the other hand, development and spatial guidelines can also be too confining if they are written in a way that limits or restricts what one can do.

\subsection{Pattern languages}

A pattern (as used in this article) is a general solution to a recurring problem in a particular context, and a pattern language is where patterns are linked together to create a broader whole (Leitner, 2015: 66). The concept of pattern languages was developed by the architectplanner Christopher Alexander and his colleagues in the 1960s and 1970s. It gained more public attention after the publication of the book titled $A$ pattern language (Alexander et al., 1977).
Alexander and his colleagues developed the pattern language approach in response to poor-quality buildings and human settlements that, he opined, were being built at the time. Urban planners were assigning land-use activities into clearly demarcated areas: for residing, working and playing, with the car playing a central role in moving people from one area to the other (Mehaffy, 2017). Alexander and Jane Jacobs (a social critique activist of the 1960s), among others, were beginning to question whether it was still wise to leave the development of neighbourhoods and spaces to planners, engineers, and architects, who, they claimed, were creating 'dead' spaces that may have looked good to some on the covers of architectural magazines, but that were spaces in which, they claimed, people did not want to be (Mehaffy, 2008). Alexander et al. (2012: 2) went so far as to claim that, 
during the $20^{\text {th }}$ and the start of the $21^{\text {st }}$ century, we as society, including architects, planners, developers, and builders were building environments that "became progressively more sterile, decade by decade, and rarely, almost never, provided the kind of environments in which people are emotionally nourished, genuinely happy, excited, romantic, loving, inspired, moved to tears or deeply contented. This gradual, steady deterioration of environmental quality has been occurring all over the world, on every continent, in every society and culture and in every nation state". Alexander's entire life's work has been dedicated to finding ways to address this fundamental problem: to develop buildings and neighbourhoods that bring beauty and life back into our environments.

A pattern language (Alexander et al., 1977) describes 253 patterns, starting from those at the scale of regions and towns (94 patterns), through patterns associated with buildings (110 patterns), and to patterns related to construction (49 patterns). Each pattern is written using the same template that includes a pattern number and title; examples of how the pattern relates to higher scale patterns; a description of the problem that the pattern aims to address; an investigation into, and motivation for why the pattern is proposed; a suggested solution to the problem (this is the core of the pattern) accompanied by a rough sketch showing how this pattern manifests in space, and further links to other lower scale patterns to which that pattern relates. Figure 2 shows an example of a pattern from $A$ pattern language (Alexander et al., 1977: 34-35), which excludes the page showing the heading and picture.

Patterns help resolve conflicting forces or problems in the environment (Alexander et al., 1977: xii).
For example, in response to the problem that people want the benefits of both country life and city life, Alexander and his colleagues (1977: 31) developed the pattern called LACE OF COUNTRY STREETS (5): ${ }^{4}$ “... place country roads at least a mile apart, so that they enclose squares of countryside and farmland at least a square mile in area. Build homesteads along these roads, one lot deep, ... with open countryside or farmland behind the houses". In response to the problem of people wanting to be able to grow food, while also being able to protect it from vandalism, and so forth, the VEGETABLE GARDEN (177) pattern reads: "set aside one piece of land either in the private garden or on common land as a vegetable garden ... Make sure the vegetable garden is in a sunny place and central to all the households it services.

$4 \quad$ Alexander's convention of writing patterns in capital letters together with the number of the pattern concerned is used.

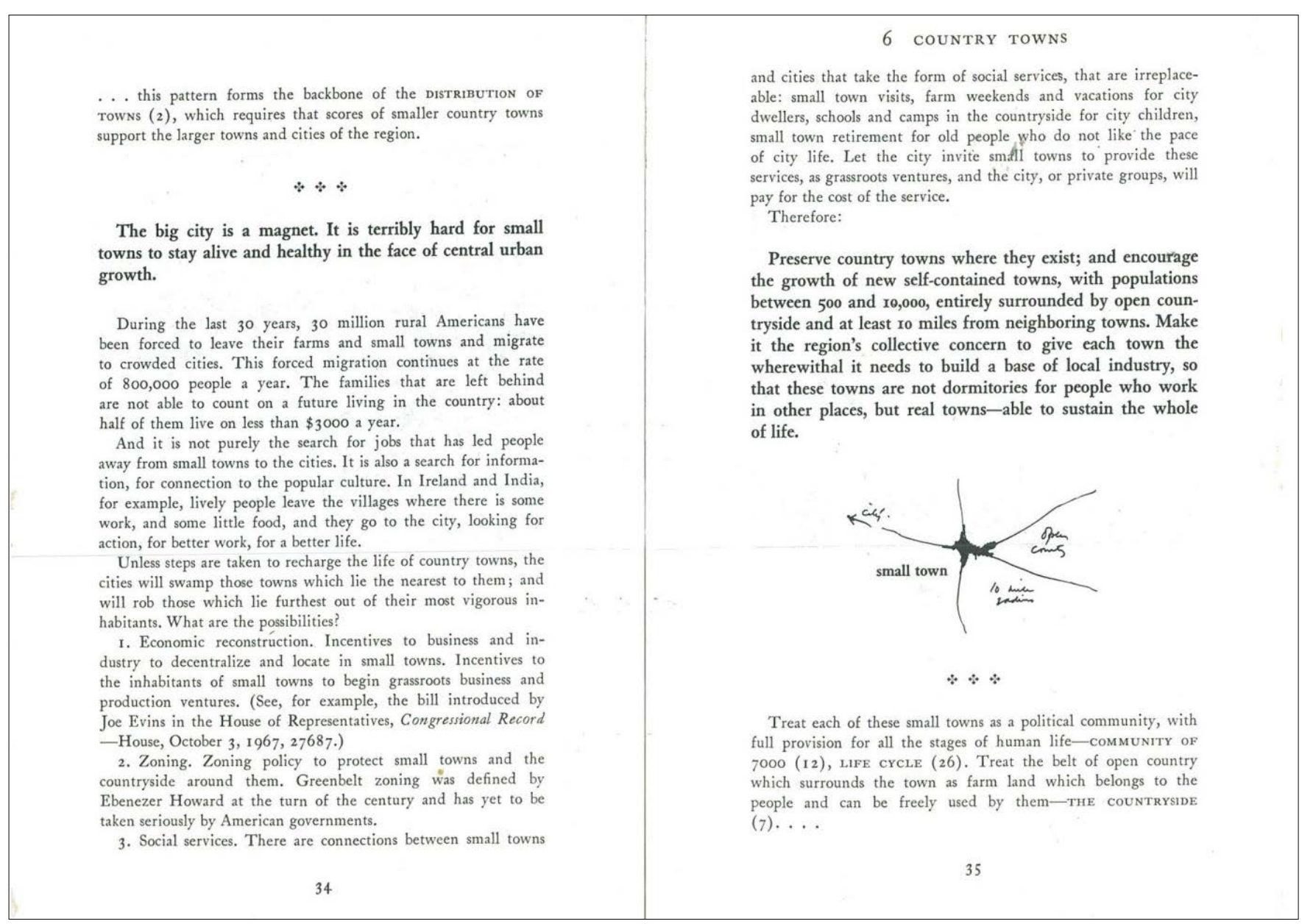

Figure 2: Copy of pattern country towns (6)

Source: Alexander et al., 1977: 34-35 
Fence it and build a small storage shed for gardening tools beside it" (Alexander et al., 1977: 818).

Individual patterns relate to other patterns at a similar, higher, and lower scale. A pattern language examines how the patterns relate to each other to form a whole that is greater than the sum of the parts as a result of patterns interacting in ways that create more 'life' than if they were working on their own (Mehaffy, 2017). A good environment is not simply a bundle of patterns, but rather a 'poem' of patterns all interrelated to each other in well-crafted ways (Alexander et al., 1977: xli). When well-articulated patterns are combined in good ways, they create environments in which people feel 'alive' and like to be (Alexander, 1979). Alexander claims that environments where people feel most alive are those that have the highest density of interrelated patterns (Alexander, 1979).

Alexander and his colleagues (1977: xvi) developed their pattern language with the understanding that every society will develop its "own unique and distinct pattern language". In the African context, Steyn (2006) developed a pattern language for the Kenyan city of Malindi. Steyn notes that a different set of patterns, especially at the neighbourhood and household level, would emerge in other cultures and contexts, and calls for more investigation into what these different pattern languages could be like.

According to Alexander (1979: 25-40), the objective of planners and anyone wanting to intervene in the spatial environment, is to work towards "the quality without a name". This is the quality of a space where the users of the space feel good being in that space - they feel more 'alive' and 'whole'. A pattern language is not a template to be applied rigidly to given contexts, but rather provides guidelines for how to respond to common challenges found in different situations.
The pattern language, read in its totality, describes the whole or 'vision' towards which one is moving. "[T]he idea is that the language of patterns captures the essential 'goal' of the people and of the place, and gets the essentials fixed in people's minds strongly enough so that it becomes the basis for their dreams, and a practical basis for acts of planning and construction by any number of participants, as the neighbourhood gets shaped and built" (Alexander, 2005: 261).

Dawes and Ostwald (2017) have categorised and mapped the various critiques of Alexander's pattern language work over the years into those that relate to the conceptualisation of pattern languages, how the patterns were developed, and how they have been implemented. In terms of conceptualisation, Alexander is criticised for his "rejection of pluralist values and subjective world-view in favour of a singular and objective one" (Dawes \& Ostwald, 2017: 4). In other words, he is criticised for claiming that everyone would agree, if they were being truthful to themselves, as to what a good quality environment is. Alexander has also been criticised for not properly documenting how he arrives at his patterns, so that others may validate or reject his findings. Neither does he pin down a clear definition of the concept of 'patterns', relying on the loose notion of patterns resolving conflicting 'forces' found in the environment. Many complain that Alexander is dogmatic in his writing, making general statements criticising others and stating that his 'timeless way of building' is the best way. This criticism has potentially put many architects and planners off Alexander's work, leaving him on the periphery of these disciplines, and potentially being one of the reasons why he has not been able to gain more mainstream recognition. In terms of implementation, Alexander has been criticised for insisting that there is only one 'right way' of building and for not allowing more flexibility in the development process.
Dawes and Ostwald (2017) contend that some of these criticisms such as not providing clear definitions and not adequately referencing how he reaches his conclusions are valid. Other criticisms such as that Alexander assumes that there is only one true way to build are less valid. Alexander himself mentions that "a pattern language" is simply that, "a" or one example of a "pattern language", and it is up to society to develop their own pattern languages for different contexts. Alexander imagined patterns to be like a hypothesis to be tested by others (Alexander et al., 1977: xv). He also indicated in his writing which patterns he believed are more valid than others (Alexander et al., 1977: xv). Alexander's own self-criticism that the use of patterns alone was not creating the quality without a name' led him to explore, in his book series The nature of order, the concept of geometric 'centres' and their 'transformation' (Dawes \& Ostwald, 2017: 3). However, despite all this criticism, Alexander's 'pattern language' concept "continues to have an enduring influence and impact on the present day" (Dawes \& Ostwald, 2017: 3). Mehaffy (2007: 48) writes that "it may be up to others to pick up many of the threads [of Alexander's work], and develop them into complete methodologies and useful new standards".

Once developed, the pattern language provides a useful tool that can help the community and development practitioners talk to each other (Erickson, 2000: online). The patterns provide a common 'language' that is understood by both sides. This reduces the likelihood that the parties will misunderstand or misinterpret each other's visions.

\section{CASE STUDY AREA}

Mooiplaas, located roughly $40 \mathrm{~km}$ north-east of East London in the Great Kei Municipality (see Figure 3), is a former 'black spot' area that was earmarked for incorporation into the Ciskei homeland by the apartheid 


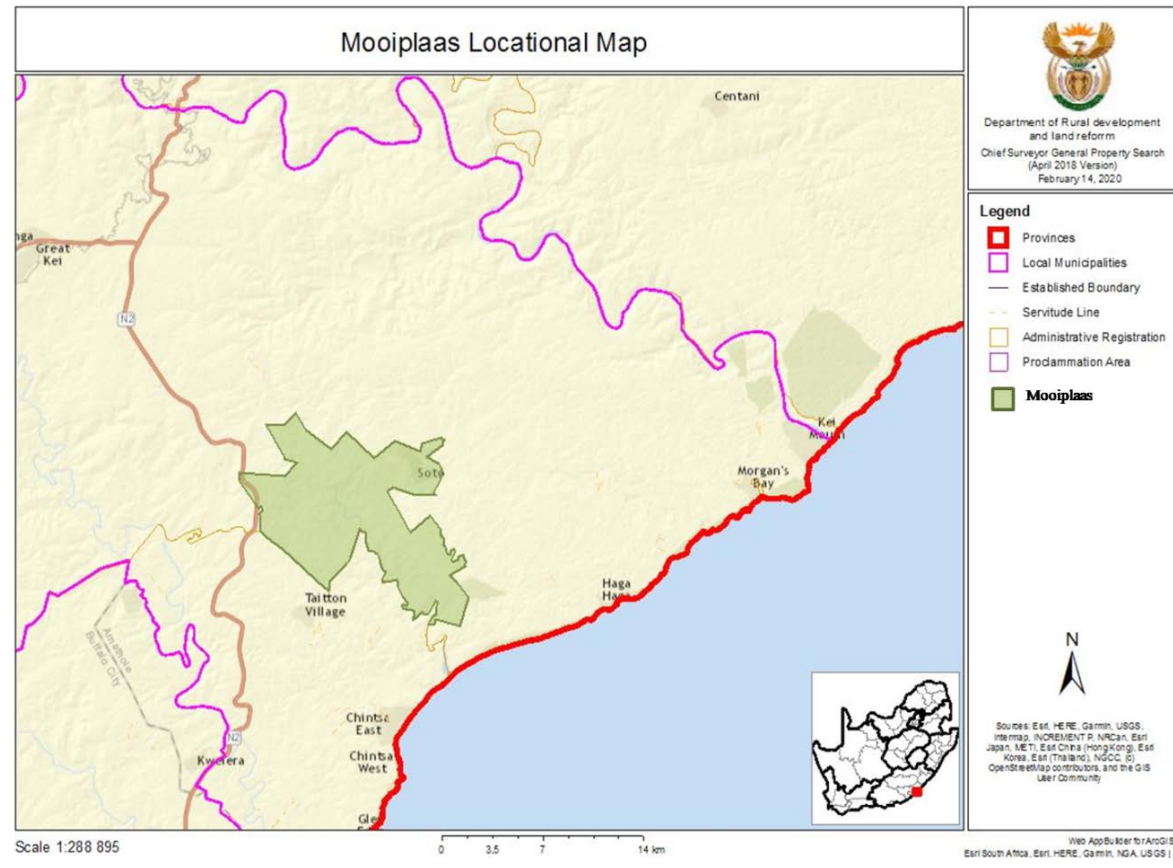

Figure 3: Location of Mooiplaas in Great Kei Municipality

Source: $\quad$ Adapted by author ${ }^{5}$ from GKM, 2018: $90^{6}$

government (Wotshela, 2014).

Residents of the area resisted being relocated and refused to be subjected to what they perceived as being an imposed headman. ${ }^{7}$ The area has a population of approximately 12,600 people (in 2011), ${ }^{8}$ located within 15 villages, ${ }^{9}$ surrounded by commercial farms. The land is owned communally in the sense that "households living on this land have, through their customary land tenure practices, strong rights to occupy and use much of this land on an individual family basis" (Housing Development Agency, 2016: 7), with many also having rights to

5 Drawn by author using Chief Surveyor Cadastral Spatial Data Viewer found at <https://csg.esri-southafrica.com/ spatialdataviewer/> based on farm boundary data obtained from landownership map on page 90 in GKM (2018)

6 This is an unpublished document of this report received from the Town Planner at the GKM. A copy is available from the author on request.

7 Key informant interview no. 5, 11 January 2019.

8 Population estimate calculated using 2011 census figures, and ward 2, 3 and 4 boundaries from 2016 local government elections, available at: <https://wazimap.co.za/profiles/municipalityEC123-great-kei/>. Note that ward boundaries do not directly correspond with Mooiplaas communal land boundaries, but have been used as a 'good enough' proxy for now.

9 Key informant interview no. 5 , 11 January 2019. use allotment gardens, communal grazing and forest areas following rules and conventions that have been developed over years, if not decades.

\section{RESEARCH}

Patterns are not simply created out of thin air; they are discovered or mined. "Like diamonds, patterns are the result of many years of process. We don't make them - we find them, we polish them, use them, and value them." (Quillien 2012: online).

Primary data were collected by fieldspecific on-site observation, which helped observe current patterns in a communal land area. Making use of qualitative case study research (Yin, 2014), the author 'mined' for patterns in the Mooiplaas communal land area. The research followed a phenomenological approach that investigated the "perceptions, perspectives, understandings and feelings of those people who have actually experienced ... the situation of interest" (Eddles-Hirsch, 2015: 252). In the Mooiplaas case, these people were the residents of Mooiplaas villages who live with the consequences of the planning or lack of planning taking place in their villages.

\subsection{Sampling}

Semi-structured interviews were held with 17 key informants to obtain their views on how planning has been, is and could be conducted in communal land areas, and on the challenges and potential vision for an area such as Mooiplaas. These informants were drawn from a mix of private sector planning consultants (seven) with experience working in rural areas; provincial and municipal government officials dealing with planning and development in communal land areas (seven), and community members (three) who have a deep understanding of the history of the Mooiplaas area. Semi-structured interviews were also conducted with 50 people from two villages within the Mooiplaas area (25 people from each village), asking them similar questions to those posed to the key informants. Purposive sampling techniques were used to get a mix of old and young, and women and men from each of the two villages. One large village located closer to the main road and one smaller village located further from the main road were identified to get people from villages of different sizes and locations.

\subsection{Pattern/data collection}

A semi-structured interview schedule included three open-ended questions:

- How was your environment developed over time? This history provides insight into what principles or patterns were consciously and/or unconsciously used in the past to develop the area over time, resulting in the current sociospatial environment.

- What problems and opportunities do you experience in your community? The problems give insight into what needs to be fixed, while the opportunities give insight into what assets the community has that can be built on.

- What is your vision for your community? This vision gives clues as to what additional features people would like to see in their environment in 
future that may not be there at the moment or may only be reflected in nascent form. It also helps identify those features of the environment that the community like and feel needs to be retained.

Interpretation between Xhosa and English was used to ensure that participants were able to express themselves in their native language. Based on the community's response to these questions, one is able to start to write a set of patterns that captures the community's vision as a pattern language. A vision that builds on what is working and that one wants to maintain and take into the future, what is problematic and needs to be fixed, as well as a vision that introduces new thinking into how the area and community can develop over time.

\subsection{Pattern/data analysis}

All key informant interviews and community semi-structured interviews were recorded and transcribed. The author undertook on-site observations during visits to the site to prepare for and conduct the community semi-structured interviews. Based on these interviews and on-site observations (as well as a literature review), a set of 295 patterns were identified. The patterns were categorised into three physical realms (natural, agricultural, and settlement) and a social realm. These realms were further categorised at the scale of the region (Great Kei Municipality and surrounding areas), the neighbourhood (the 15 Mooiplaas villages), a village, and a plot.

\section{MOOIPLAAS - DEVELOPING A PATTERN LANGUAGE}

The 295 patterns were prioritised and categorised into a set of 33 patterns (Table 1 lists their names) that were written as a draft pattern language for the Mooiplaas communal land area. This pattern language was presented during two focus group meetings of eight people from each of the two villages (drawn from the original 50 people interviewed), where participants confirmed that these patterns truly reflect the vision for how they would like their community, village and neighbourhood to be developed in future.

In the context of spatial planning and land-use management, a pattern language can be 'mined' and developed by examining the existing environment and finding those patterns or features that one wants to keep. For example, one may like and want to keep the grazing land and communal allotments found around rural villages. These features can then be expressed as patterns (see patterns 1 to 5 in Table 2 for examples of existing patterns). One can then also develop a new set of patterns that bring in new features that one wants to see in the future environment (see patterns 6 to 10 in Table 2 for examples of new patterns). For example, in a group of rural villages, there may not be a clear neighbourhood node where people in that neighbourhood congregate; a 'node' pattern can thus be written. A combination of these existing and new patterns forms a pattern language - providing a vision for what type of environment the community would like to work towards.

\subsection{An example of pattern language for Mooiplaas}

The patterns presented in Table 2 are summarised examples, drawn from the initial list of 295 patterns identified for Mooiplaas. These patterns are associated with a particular communal land area where people have historically (since the mid $20^{\text {th }}$ century) and culturally lived in rural villages. A very different set of patterns would emerge if one was viewing, for example, a pattern language for a more dispersed rural homestead area or a township area.

A pattern language shows how these various patterns relate to each other. For example, the HUB OF GOVERNMENT SERVICES is located near the PUBLIC TRANSPORT INTERCHANGE that is found in the centre of the NEIGHBOURHOOD NODE, which is one of the locations for a PERIODIC MARKET. SATELLITE RESOURCE CENTRES are accessible to people living in HOMESTEADS that are located in villages forming a NETWORK OF VILLAGES that are surrounded by ALLOTMENT GARDENS and GRAZING LANDS and that form part of the REGIONAL LANDSCAPE.

\section{USING THE PATTERN LANGUAGE AS A VISION}

The pattern language - as a vision - provides a set of principles, guidelines or 'rules of thumb' that can be used by the community and professionals alike to help them make decisions as to whether any new development intervention being proposed for an area is helping move the community towards or away from this vision.

The pattern language provides a common language that planners, other professionals and communities

Table 1: List of draft patterns for Mooiplaas pattern language

\begin{tabular}{|c|c|}
\hline A. Regions & 17. Recreation network \\
\hline 1. Landscape realms & 18. Cultural and spiritual places \\
\hline 2. Social realm & 19. Population mix \\
\hline Scales of realms & E. Economic development \\
\hline 4. Network of settlements & 20. Local economies \\
\hline 5. Land tenure & 21. Economic support network \\
\hline 6. Organisational arrangements & 22. Local markets \\
\hline B. Broad land-use categories & 23. Tourism support \\
\hline 7. Conservation network & F. Engineering services \\
\hline 8. Agricultural realm & 24. Water and sanitation network \\
\hline 9. Network of villages & 25. Waste management system \\
\hline 10. Settlement nodes & 26. Energy network \\
\hline C. Movement & G. Local places \\
\hline 11. Road network & 27. Rural lifestyle \\
\hline 12. Public transport network & 28. Place-making \\
\hline D. Social services and facilities & 29. Special places \\
\hline 13. Learning services network & 30. Multi-purpose spaces \\
\hline 14. Health services network & 31. Homesteads \\
\hline 15. Safety and security services network & 32. Construction \\
\hline 16. Information and communication network & 33. Landscape edges \\
\hline
\end{tabular}


can use to communicate with each other about what they perceive the community to be like in the future. The pattern language is easily understood by all involved and communities can be involved in the preparation and adaptation of the pattern language over time. Patterns within a pattern language - as a vision - can be refined and improved; new patterns can be introduced, and old patterns removed over time. In this way, the pattern language can evolve, becoming increasingly more reflective of and truly capturing the community's vision of where it would like to see itself going.

Pattern languages need to be tested to verify their authenticity. In this way, patterns are like hypotheses that provide an informed statement of how challenges experienced in the environment can be overcome and how opportunities can be built on (Alexander, 1977: xv). Over time, more empirical evidence can be collected to help better articulate the problems and opportunities being confronted as well as confirm and refine the proposed solutions to respond to these problems and opportunities.

Table 2: Example of pattern language for Mooiplaas - in the context of a rural village neighbourhood within a communal land area

Existing patterns: Patterns 1 to 5 provide examples of patterns drawn from what can be observed and as expressed by people living in the area.

\section{REGIONAL LANDSCAPE}

Problem: Communal village areas lose their rural character if the wilderness, agriculture and settlement balance is lost.

Solution: Develop an interconnected network of settlements, agricultural lands, and wilderness land.

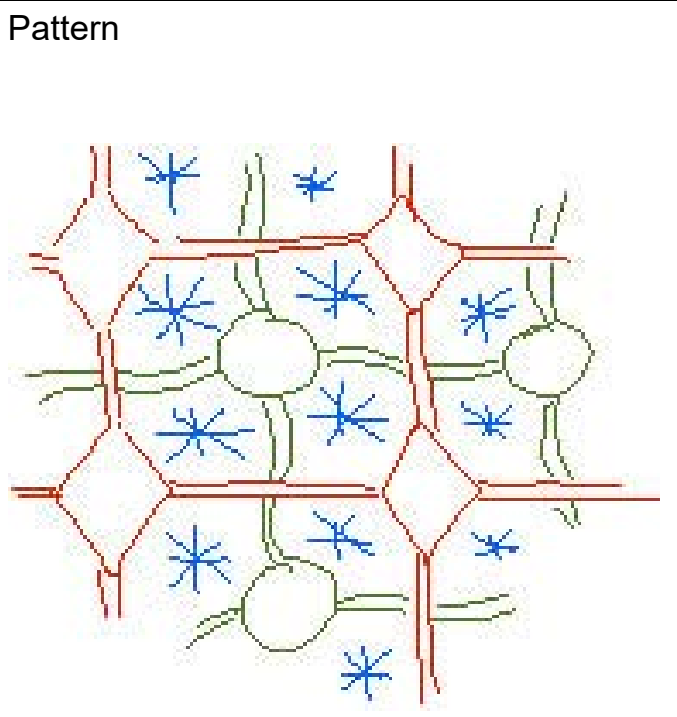

\begin{tabular}{|l|l}
\hline Key & Settlement realm \\
\hline & Wilderness realm \\
\hline if & Agricultural realm \\
\hline
\end{tabular}

\section{NETWORK OF VILLAGES}

Problem: If settlements get too big, they lose their connection to agriculture and wilderness. If homesteads are too spread out, it is difficult for government to provide schools, clinics, etc.

Solution: Cluster households and other facilities within villages and link existing and new villages together within a road network.

Pattern


Table 2: Continued...

\section{ALLOTMENT GARDENS}

Problem: Homestead plots in villages are too small for people to undertake certain agricultural activities. Solution: Create allotment gardens on good agricultural lands within walking distance of people in the village.

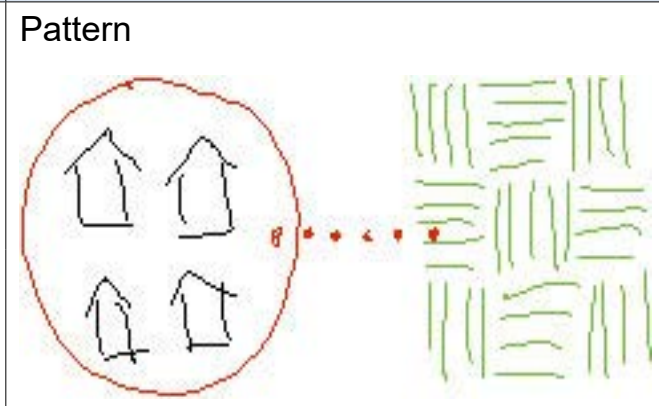

\begin{tabular}{|l|l}
\hline & Key \\
\hline
\end{tabular}

4 GRAZING LANDS

Problem: If grazing lands are not managed as settlements expand, they get lost to sprawling settlements. Solution: Identify, preserve and provide grazing lands on the edge of villages to be used by village members.

\begin{tabular}{ll|l|l|}
\hline Pattern & Village \\
\hline
\end{tabular}

\section{HOMESTEAD}

Problem: If residential plots become too small and people are unable to use the plot for multiple agricultural and cultural purposes, the settlement becomes more like a township.

Solution: Establish medium-sized plots that can be used by families for multiple purposes from residential to household gardens and home-based businesses.

Pattern

\begin{tabular}{|l|l|}
\hline Key & Village \\
\hline
\end{tabular}


Table 2: Continued...

New patterns: Patterns 6 to 10 provide examples of possible new patterns that are the outcome of the visions of people living in the Mooiplaas area and drawing on best practice research.

\section{NEIGHBOURHOOD NODE}

Problem: If activities (such as shops, factories and government facilities) are scattered, it makes it difficult for these activities to sustain themselves and for people to get to them.

Solution: Cluster the main activities in a central location within the community, accessible to people from multiple villages.

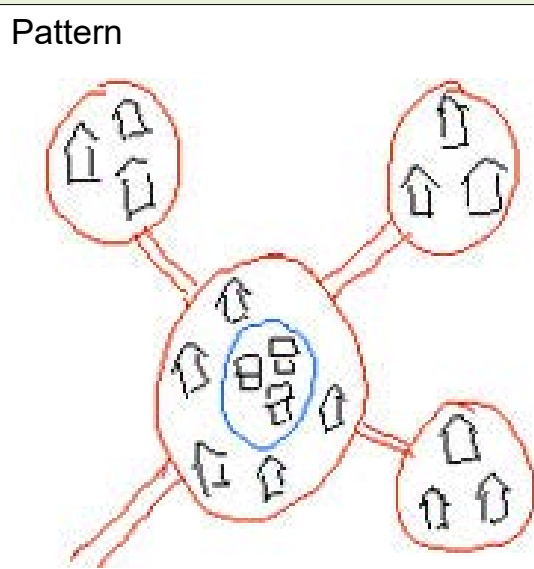

\begin{tabular}{|l|l|}
\hline Key & Village \\
\hline & Neighbourhood node \\
\hline
\end{tabular}

\section{PUBLIC TRANSPORT INTERCHANGE}

Problem: People in villages need to be able to get to multiple destinations, but they struggle to do so if others in their village are not going in that direction.

Solution: Provide a public transport interchange within a neighbourhood node that forms the gateway into and out of the neighbourhood.

\begin{tabular}{l|l|l|} 
Pattern & Public transport interchange \\
\hline
\end{tabular}


Table 2: Continued...

\section{HUB OF GOVERNMENT SERVICES}

Problem: It is inconvenient for people if they have to make separate trips to access different government services.

Solution: Cluster government facilities and services within a hub of government services.

Pattern

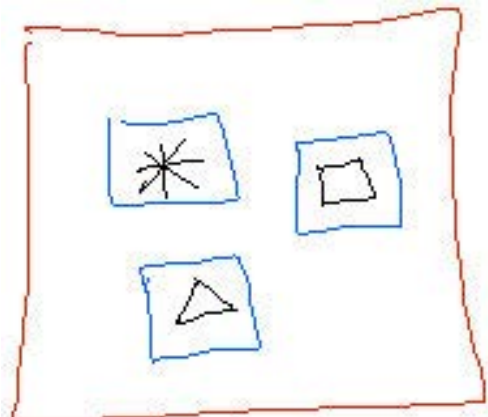

Key

Government services
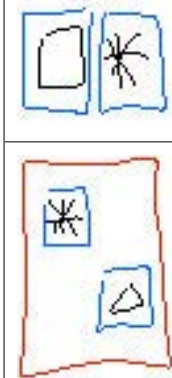

Hub of government services

\section{PERIODIC MARKET}

Problem: It is difficult for markets to thrive if there are not enough people in the area who are able to access and make use of the market in a sustainable way.

Solution: Spread market days across different villages so that each village has its own market day in a fixed location as part of a rotating schedule.

Pattern

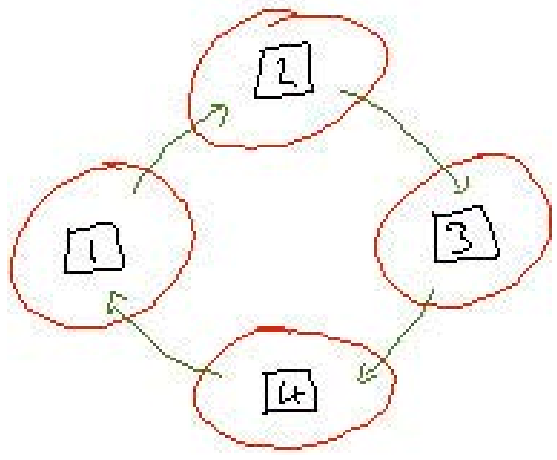

Key

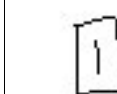

Market place and day

Village

Marketing circuit

10 SATELLITE RESOURCE CENTRES

Problem: It is expensive for all schools to have their own libraries and resource centres.

Solution: Establish satellite resource centres in villages, managed as part of a neighbourhood resource centre network, where people are able to access the internet and obtain advice from local volunteers in a safe space.

Pattern

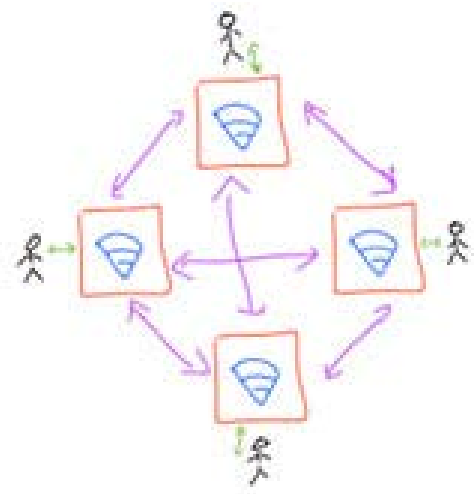

\begin{tabular}{|l|l|}
\hline & Satellite resource centre \\
\hline & Access to internet \\
\hline & People access resources \\
\hline
\end{tabular}


More research is needed to determine the extent to which a pattern language, when used to capture a community's vision, can be incorporated into the IDP process, the SDF plans and the land-use management process of the municipality. For example, it may be possible for a municipality, following a participatory planning process, to develop and approve a specific pattern language for a specific landscape context in their municipal area (such as a communal land area) and have this pattern language approved as part of the municipal SDF. In future, when a landowner, the community, a developer or a government department wants to undertake a new development project within that area (such as convert agricultural land to residential land, or build a new garage and shop on an existing residential piece of land), the Municipal Planning Tribunal could use the pattern language to help inform them if they should approve or reject that land-use change application. Over and above the municipality and Municipal Planning Tribunal having to consider the national spatial principles found in section 2 of SPLUMA, the content of the municipal IDP (with its associated vision statement), the SDF plan and any spatial and development principles incorporated in these documents, they would now also have to consider the approved pattern language.

In this way, the community's vision, expressed as a pattern language, takes on a real meaning in the municipal development process. The vision is not simply some 'feel good' vision statement that sits in a report or is shown on a pretty SDF map that brightens the wall of a government official's office. It is a pattern language that sits in the hearts and minds of those who helped develop it; it is a vision that legally needs to be considered by all decision-making authorities when land-use change decisions are made (RSA, 2013: s12.2(b)).

\section{CONCLUSION AND FURTHER RESEARCH}

The article demonstrated that it is possible to develop a pattern language for a specific rural community. The pattern language does help capture and articulate the community's vision. More research, similar to the Mooiplaas research, is needed to investigate whether pattern languages can be developed in other areas, in order to capture the visions of other communities. Research is also required to determine the extent to which a pattern language can be used within the context of the existing spatial planning and land-use management processes, as provided for by the SPLUMA. Part of this additional research involves piloting and testing the use of pattern languages within actual communities and municipalities.

The article also stated that existing tools such as vision statements, SDF plans and spatial development principles are insufficient tools to adequately capture a community's vision. As a result, they do not significantly inspire action in pursuit of this vision. These assertions need to be further tested through additional empirical research.

The pattern language has the potential to be used within the spatial planning and land-use management process in the country, especially in communal land areas that have not been part of formal municipal planning and land-use management processes in the past. We are only at the very early stages of exploring this potential, and much more research and piloting is needed to reach a stage where pattern languages become a key feature within the spatial planning and land-use management toolbox.

\section{REFERENCES}

ALEXANDER, C. 1979. The timeless way of building. Centre for Environmental Structure Series, volume 1. New York: Oxford University Press.
ALEXANDER, C. 2005. A vision of a living world. Book 3. Centre for Environmental Structure Series, volume 11: The nature of order. Berkeley, CA: Centre for Environmental Structure.

ALEXANDER, C., ISHIKAWA, S., SILVERSTEIN, M., JACKOBSON, M., FIKSDAHL-KING, I. \& ANGEL, S. 1977. A pattern language, towns, buildings, construction. Centre for Environmental Structure, volume 2. New York: Oxford University Press.

ALEXANDER, C., NEIS, H., ANNINOU, A. \& KING, I. 1987. A new theory of urban design. New York: Oxford University Press.

ALEXANDER, C., NEIS, H. \& MOREALEXANDER, M. 2012. The battle for the life and beauty of the earth: A struggle between two world views. New York: Oxford University Press.

BHATTACHARYYA, S. 2016. Five Differences between setting a goal and a vision. [Online]. Available at: <https:// yourstory.com/2016/08/differencebetween-goals-vision>. [Accessed: 3 May 2019].

COMMUNITY TOOLBOX. n.d. Chapter

8. Developing a strategic plan, Section 1. An overview of strategic planning or "VMOSA" (vision, mission, objectives, strategies, and action plans). [Online]. Available at: <https://ctb.ku.edu/en/tableof-contents/structure/strategic-planning/ vmosa/main>. [Accessed: 3 May 2019].

DAWES, M.J. \& OSTWALD, M.J. 2017. Christopher Alexander's A pattern language: Analysing, mapping and classifying the critical response. City Territory and Architecture, 4(1), pp.1-14. https://doi.org/10.1186/ s40410-017-0073-1.

EDDLES-HIRSCH, K. 2015. Phenomenology and educational research. International Journal of Advanced Research, 3(8), pp. 251-260.

ERICKSON, T. 2000. Lingua francas for design: Sacred places and pattern languages. In: Boyarski, D. \& Kellogg, W. (Eds). Proceedings of DIS'2000: Designing interactive systems, 17-19 August, New York: Brooklyn. Association for Computing Machinery Press, pp. 357-368. [Online]. Available at: <http://www.pliant.org/personal/ Tom_Erickson/LinguaFranca_DIS2000. html>. [Accessed: 12 February 2019]. 
GKM (GREAT KEI MUNICIPALITY).

2016. Great Kei Municipality Spatial Development Framework 2016. Unpublished.

GKM (GREAT KEI MUNICIPALITY). 2017. Great Kei Municipality Integrated Development Plan 2017-2022. [Online]. Available at: <https://greatkeilm.gov.za/ document/2017-2022-draft-integrateddevelopment-plan-2/>. [Accessed: 3 May 2019].

GKM (GREAT KEI MUNICIPALITY). 2018. Great Kei Local Municipality Land Audit - August 2018. Unpublished.

HOUSING DEVELOPMENT AGENCY. 2016. Rethinking communal land administration: Unlocking human settlements development in communal land area. [Online]. Available at: <http:// www.incrementalsettlement.org.za/ wiki/images/a/af/HDA_Communal_ draft_3_\%284\%29_sept_2016.pdf $>$. [Accessed: 3 May 2019].

LEITNER, H. 2015. Pattern theory, introduction and perspectives on the tracks of Christopher Alexander. Pattern Research Series 001. Published by Helmut Leitner, HLS SOFTWARE.

MEHAFFY, M.W. 2007. Notes on the genesis of wholes: Christopher Alexander and his continuing influence. Urban Design International, 12(1), pp. 41-49. https://doi.org/10.1057/ palgrave.udi.9000182.

MEHAFFY, M.W. 2008. Generative methods in urban design: A progress assessment. Journal of Urbanism: International Research on Placemaking and Urban Sustainability, 1(1), pp. 57-75. https://doi. org/10.1080/17549170801903678.

MEHAFFY, M.W. 2017. Cities alive: Jane Jacobs, Christopher Alexander, and the roots of the New Urban Renaissance. Portland, OR: Sustasis Press.

ON STRATEGY. n.d. Phase 2: Developing strategy. [Online]. Available at: <https://onstrategyhq.com/resources/ developing-your-strategy/>. [Accessed: 3 May 2019].

RSA (REPUBLIC OF SOUTH AFRICA). 2000. Municipal Systems Act, No. 32 of 2000. Pretoria: Government Printer.
RSA (REPUBLIC OF SOUTH AFRICA). 2013. Spatial Planning and Land Use Management Act, Act 16 of 2013. Pretoria: Government Printer.

RURAL DEVELOPMENT AND LAND REFORM. 2011. Guidelines for the development of Spatial Development Frameworks. [Online]. Available at: $<$ http://www.ruraldevelopment.gov. za/phocadownload/spatial_Planning Information/Simplified_Guideline.pdf $>$. [Accessed: 3 May 2019].

SHIPLEY, R. 2002. Visioning in planning: Is the practice based on sound theory? Environment and Planning A, 34(1), pp. 7-22. https://doi. org/10.1068/a3461.

SOUTH AFRICAN CITIES NETWORK. 2015. SPLUMA as a tool for spatial transformation. [Online]. Available at: $<$ http://www.sacities.net/wp-content/ uploads/2015/SPLUMA-as-a-toolfor-spatial-transformation_final.pdf $>$. [Accessed: 3 May 2019].

STEYN, G. 2006. A pattern language as a tool for studying African urbanism using Malindi, Kenta, as a case study. South African Journal of Art History, 21(2), pp. 10-26.

QUILLIEN, J. 2012. Pattern language stories: History from a pattern language to the nature of order. [Online]. Available at: <https://www.wd-pl.com/history-2/>. [Accessed: 12 October 2017].

WOTSHELA, L. 2014. Quitrent tenure and the village system in the former Ciskei region of the Eastern Cape: Implications for contemporary land reform and a century of change. Journal of Southern African Studies, 40(4), pp. 727-744. https://doi.org/10.10 80/03057070.2014.931063.

YIN, R. 2014. Case study research: Design and methods. 5th edition. Thousand Oaks, CA: SAGE Publications. 